\title{
Technology Acceptance Model: A Review of the Prior Predictors
}

\section{Ummuhan AVCI YUCEL ${ }^{*}$ Yasemin GULBAHAR ${ }^{* *}$}

\begin{abstract}
This study aims at analyzing possible predictors of technology acceptance model based on qualitative review of relative articles. Thus, within the scope of this study articles which had based their theoretical framework on Technology Acceptance Model (TAM) were screened. For this reason, fifty papers, which were published in thirty-two journals and nine conferences between the years 1999 and 2010, were reviewed. In terms of the articles reviewed, search results revealed that most of the research studies were in the fields of education and business. These papers were examined with three main objectives in mind: (1) to investigate TAM variables that were found effective and ineffective from a critical point of view; (2) to highlight the top use of the effective variables; (3) to compose the study fields of TAM. These papers were analyzed through content analysis by an inductive approach. In the first stage coding was carried out according to previously identified concepts (scanning, selection criteria) and themes that were emerged in this context. Then the data were organized and grouped according to themes and presented by means of making numerical transformation in appropriate cases. Finally, the obtained findings were interpreted. The results showed that the main variables of "Technology Acceptance Model" were remained as the most effective ones though numerous attempts have been made to add other variables to existing ones.
\end{abstract}

Keywords: Technology Acceptance Model (TAM); content analysis.

\footnotetext{
* Res. Assist., Başkent University, Faculty of Education, Department of Computer Education and Instructional Technology, Ankara, Turkey. E-mail: uavci@baskent.edu.tr

${ }^{* *}$ Assoc. Prof. Dr., Ankara University, Department of Informatics, Ankara, Turkey.

E-mail: gulbahar@ankara.edu.tr
} 


\section{ÖZET}

Amaç ve Önem: Teknoloji Kabul Modeli (TKM) kullanıcıların teknoloji karşısındaki davranışlarını açıklamaya yönelik Davis (1989) tarafindan ortaya konulmuş bir modeldir. Bu modelin temel amaçlarından biri içsel inanç, tutum ve niyeti etkileyen dışsal değişkenleri incelemektir. $\mathrm{Bu}$ modelin en temel iki değişkeni kullanım kolaylığı ve yararlılıktır. $\mathrm{Bu}$ çalışmada teknoloji kabulünün olası yordayıcılarını nitel analiz yoluyla incelemek amaçlanmıştır. Kuramsal çerçevelerini Teknoloji Kabul Modeli'nin oluşturduğu makaleler bu çalışmanın hedefini oluşturmaktadır. $\mathrm{Bu}$ nedenle 1999 ve 2010 yılları arasinda 32 dergi ve 9 konferansta yayınlanmış olan 50 makale incelenmiştir. Bu makaleler üç temel ölçüt esas alınarak incelenmiştir: (1) etkili ve etkisiz bulunan TKM değişkenlerini kritik bir bakış açısıyla incelemek; (2) en etkili bulunan değişkenlerin kullanımını vurgulamak; (3) TKM'nin çalışma alanlarını ortaya çıkarmak. Bu makaleler daha çok şu dergi ve konferanslardan alınmıştır: Computers \& Education, International Journal of Information Management, Journal of Computer Information Systems, Cyberpsychology \& Behavior, Decision Support Systems, Educational Computing Research and Behaviour \& Information Technology. Bütün bu dergilere ise şu veritabanları kullanılarak erişilmiştir: Elsevier-ScienceDirect, Springer, TÜBİTAK EKUAL, Taylor \& Francis, EBSCO Host ve Blackwell.

Yöntem: $\mathrm{Bu}$ makaleler tümevarımsal yaklaşım ile içerik analizi kullanılarak analiz edilmiştir. $\mathrm{Bu}$ nedenle bu çalışma meta analiz çalışmasından çok nitel bir analiz olan içerik analizi çalışması olarak adlandırılmıştır. $\mathrm{Bu}$ mevcut çalışma TKM araştırmalarının genel olarak incelenmesine bir değer katmaya çalışan benzer çalışmaların bir alt grubu olarak düşünülebilir. $\mathrm{Bu}$ çalışmanın ilk aşamasında daha önceden tanımlanmış kavramlara göre kodlama yapılmış (tarama, ölçüt belirleme) ve bu bağlamda temalar (benzer değişkenleri tek bir başlık altında toplamaya yönelik temalar (yarar, kullanım kolaylığı, niyet vb.), değişkenlerin birbiriyle yakınlık derecesine göre belirlenmiş temalar (içerik/ders, yazılım ve araçları, öğrenen ve öğretici, örgütsel konular), değişkenlerin çalışıldığı ilgili alanlara yönelik temalar (eğitim, iş ve diğerleri)) elde edilmiştir. Daha sonra veriler temalara göre organize edilmiş, gruplanmış ve uygun durumlarda sayısallaştırılmıştır.

Bulgular: Bahsi geçen makalelerin içerik analizi ile incelenmesinden sonra listelenen değişkenler, birbirleriyle ilgili olmaları durumuna göre ana temalar altında gruplandırılmıştır. İlgili değişkenler incelenen makalelerde en etkili, etkisi anlamlı ve etkisiz bulunmaları doğrultusunda incelenmiş ve 
etkili bulunma derecelerine göre sıralanmıştır. "Algılanan yarar" değişkeninin makalelerde en fazla kullanılan ve etkili bulunan değişken olduğu belirlenmiştir. $\mathrm{Bu}$ değişkeni "algılanan kullanım kolaylığı, niyet, sistem ve araçların incelenmesi ve teknolojik yetkinlik" değişkenleri sırasıyla izlemiştir. "Kaygı" değişkeninin ise incelenen makalelerde en az etkili bulunan değişken olduğu belirlenmiştir. İncelenen makalelerde birbiriyle ilgili olmalarına göre gruplanan değişkenler yine ilgili temalar altına yerleştirilmiştir. $\mathrm{Bu}$ temalar ders/içerik, yazılım ve araçlar, öğrenen/öğretici ve örgütsel konular olmak üzere 4'e ayrılmıştır. İncelenen makalelerin daha çok eğitim başta olmak üzere iş alanında da yapıldığı dikkat çekmiştir.

Tartısma, Sonuç ve Öneriler: Teknolojinin kabulü ya da reddi tek bir değişkenle açıklanamayacak kadar karmaşık bir süreçtir. Ancak yaşamın tüm alanını etkileyen bu yeniliklerin hangi özelliklerinin kabul veya reddedilmeye sebebiyet verdiği bilinmesi gereken önemli bir konudur. $\mathrm{Bu}$ nedenle bu süreçleri etkileyen değişkenlerin bilinmesi önem taşımaktadır. $\mathrm{Bu}$ araştırmanın sonuçları birçok yeni değişkenin var olan değişkenlere eklenmesine rağmen TKM'deki temel değişkenlerin (algılanan yarar, algılanan kullanım kolaylığı, niyet) en etkili olarak kaldığını göstermiştir. Teknoloji şekil, boyut hız vb. özellikleriyle bu kadar hızlı değişirken ve çeşitlilik gösterirken değişkenlerin aynı kalması ilginç bir sonuçtur. Ayrıca TKM üzerinde yapılan araştırmaların temel olarak eğitim ve iş alanlarını kapsadığı görülmüştür. Bu durumun sebepleri düşünüldüğünde bilginin daha çok bu alanlarda yayıldığı akla gelmektedir. Bilginin yayılımının da İnternet aracılı̆̆ıyla gerçekleştiği düşünülürse teknolojinin en çok bu alanlarda yayılması ve bu alanların da teknolojiyle hızla değişmesi beklenen bir sonuç olarak karşımıza çıkmaktadır. Günümüzün vazgeçilmez ögeleri olan bilgi, teknoloji, eğitim ve iş döngüsünü düşündüğümüzde bu alanların birbirini etkileyen alanlar olduğu söylenebilir. $\mathrm{Bu}$ nedenle herhangi bir yeniliğin birbirinden etkilenen bu alanlar arasından yayılması da kaçınılmazdır. $\mathrm{Bu}$ çalışmayla birlikte gelecekte yapılacak araştırmalar için çeşitli öneriler de getirilmiştir. Günümüzde kullanımı çok fazla bilgi gerektirmeyen araçlar geliştirilmiştir. Bu araçlar teknoloji kullanma becerilerini en az seviyeye indirmektedir. $\mathrm{Bu}$ nedenle bu araçların gelişimiyle birlikte teknoloji kabulünde ön plana çıkan değişkenlerin farklılaşıp farklılaşmayacağı, etkilerinin ne düzeyde olacağı ya da yeni değişkenlerin bu sürece dâhil olup olmayacağı da araştırılması gereken diğer konulardır. 


\section{Teknoloji Kabul Modeli: Önceki Yordayıcıların İncelenmesi}

\section{Ümmühan AVCI YÜCEL ${ }^{*} \quad$ Yasemin GÜLBAHAR**}

ÖZ. Bu çalışmada teknoloji kabulünün olası yordayıcılarını nitel bir incelemeyle analiz etmek amaçlanmıştır. Kuramsal çerçevelerini Teknoloji Kabul Modeli (TKM)'nin oluşturduğu makaleler bu çalışmanın hedefini oluşturmaktadır. Bu nedenle 1999 ve 2010 yılları arasında 32 dergi ve 9 konferansta yayınlanmış olan 50 makale incelenmiştir. Araştırma sonuçlarında incelenen makalelerin çoğunluğunun eğitim ve iş alanları hakkında olduğu görülmüştür. $\mathrm{Bu}$ makaleler üç temel hedefe yönelik incelenmiştir: (1) etkili ve etkisiz bulunan TKM değişkenlerini kritik bir bakış açısıyla incelemek; (2) en etkili bulunan değişkenlerin kullanımını vurgulamak; (3) TKM'nin çalışma alanlarını ortaya çıkarmak. Bu makaleler tümevarımsal yaklaşım ile içerik analizi kullanılarak analiz edilmiştir. Bu çalışmanın ilk aşamasında daha önceden tanımlanmış kavramlara göre kodlama yapılmış (tarama, ölçüt belirleme) ve bu bağlamda temalar elde edilmiştir. Daha sonra veriler temalara göre organize edilmiş, gruplanmış ve uygun durumlarda sayısallaştırılmıştır. Son olarak elde edilen bulgular yorumlanmıştır. Sonuçlar birçok yeni değişkenin var olan değişkenlere eklenmesine rağmen TKM'deki temel değişkenlerin en etkili değişkenler olarak kaldığını göstermiştir.

Anahtar Sözcükler: Teknoloji Kabul Modeli, içerik analizi.

\footnotetext{
${ }^{*}$ Arş. Gör., Başkent Üniversitesi Eğitim Fakültesi Bilgisayar ve Öğretim Teknolojileri Eğitimi Bölümü Ankara, Türkiye. E-posta: uavci@baskent.edu.tr

"Doç. Dr., Ankara Üniversitesi Enformatik Bölümü Ankara, Türkiye. E-posta: gulbahar@ankara.edu.tr
} 


\section{INTRODUCTION}

The unprecedented growth of the Internet together with the progress of web technologies has given rise to widespread use of many electronic-based applications such as e-learning, e-business and e-government across many different disciplines. Moreover, the increasing availability of wireless and mobile technologies makes these kinds of internet-based electronic applications even more ubiquitous and pervasive. However, although these technologies create possibilities for new ways of engagement and invite innovative approaches, a digital transformation is required for people in different disciplines in terms of attitudes and ability to cope with this technology (Yuena and Ma, 2008). Thus, since internet participation has been increasing throughout various disciplines, the importance placed on the processes of technology adoption has likewise increased (Fusilier, Durlabhji and Cucchi, 2008). Furthermore, the real benefits of this technology for deciding on use or not to use are always subject to change. This concern is at least partially based on the use and acceptance of the related technologies by its intended users.

Technology acceptance or adoption has received considerable attention in the last decade. Researchers and organizations have therefore been trying to find factors that influence an individual's acceptance of technology, thereby ultimately enhancing its usage. Several theoretical models have been proposed to explain the users' acceptance behavior. Among them, Technology Acceptance Model (TAM), which is currently the prevalent predictive tool for testing user acceptance of new technologies, proposed by Davis (1989) is widely applied and empirically tested. There have been tens of empirical studies conducted on TAM since its inception. Compared with its competing models, TAM is believed to be more parsimonious, predictive, and robust (Venkatesh \& Davis, 2000).

Technology acceptance can be interpreted as the observable willingness to make use of information technology while working on the tasks to be accomplished. However, it is known that not all the individuals who wish to use technology in their daily lives make real use of technology. Therefore, investigating the underlying factors which lead people to accept technology, in other words, the reasons that influence people in the adoption process, is a significant phenomenon. In order to reveal these factors which influence the process of adaptation, many researchers have conducted studies in order to maximize the potential for acceptance (Fusilier, Durlabhji and Cucchi, 2008). The literature on technology acceptance is wide-ranging and it is certain that the level of acceptance can be explained best by considering a number of variables (Chuttur, 2009; Dillon, 2001; Dillon \& Morris, 1996; Turner et al., 2010). 
Technology Acceptance Model (TAM) has appeared to be one of the most widely used models due to its understandability and simplicity (Legris, Ingham and Collerette, 2003). TAM proposes that perceived ease of use and perceived usefulness are the predictors in the acceptance of information technology. The model has become the most extensively applied one of user acceptance and usage since its creation and it has been tested with various applications in countless studies. Nevertheless there has been a long debate on its basic characteristics and its usefulness for researches.

Reviewing the research conducted about "technology acceptance" should reveal the most effective variables and provide a deeper insight for clarifying behaviours that predicts technology usage which is suggested by Davis in 1989. Moreover, revealing the variables that predict technology acceptance will guide future researchers while making research studies and creating their models for innovation, diffusion and acceptance. Based on these facts, for this study 50 papers which had based their theoretical framework on TAM were examined with three major objectives in mind: 1) to provide a critical analysis of the TAM variables that were found effective and ineffective; 2) to highlight the top use of the effective variables; and 3) to bring out the working areas of TAM.

\section{Theoretical Framework}

Countless theories exist with regard to the diffusion, adoption and acceptance of innovation. Among the foremost theories are; Innovation Diffusion Theory (Rogers, 2003), The Theory of Planned Behavior (Ajzen, 1991), The Theory of Reasoned Action (Fishbein \& Ajzen, 1975), The Technology Acceptance Model (Davis, 1989) and The Unified Theory of Acceptance and Use of Technology Model (Venkatesh, Morris, Davis \& Davis, 2003).

In the Innovation Diffusion Theory (IDT), Rogers (2003) defined diffusion as "in which an innovation is communicated through certain channels over time among members of a social system". He explained the process of innovation diffusion within communication processes by including the factors that influence the potential adopters' perception about innovation during the introduction of technological innovations.

This theory is based on four main components that are innovation, communication channel, time and social system. Rogers explained that time is involved in diffusion at three points; 1) innovation decision process (knowledge, persuasion, decision, implementation and confirmation), 2) innovativeness of an individual (innovators, early adopters, early majority, late majority and laggards) and 3) an innovator's rate of adoption in a system. He explicated the difference of adoption rate with the perception of individuals about the perceived characteristics of innovation, arranged the 
following five characteristics (relative advantage, compatibility, complexity, trialability, observability) of innovation that consistently influence the adoption of new technologies (see Fig.1). Rogers (2003) defined relative advantage as "is the degree to which an innovation is perceived as being better than the idea it supersedes", compatibility as "is the degree to which an innovation is perceived as consistent with the existing values, past experiences, and needs of potential adopters", complexity as "is the degree to which an innovation is perceived as relatively difficult to understand and use", trialability as "is the degree to which an innovation may be experimented with on a limited basis", observability as "is the degree to which the results of an innovation are visible to others".

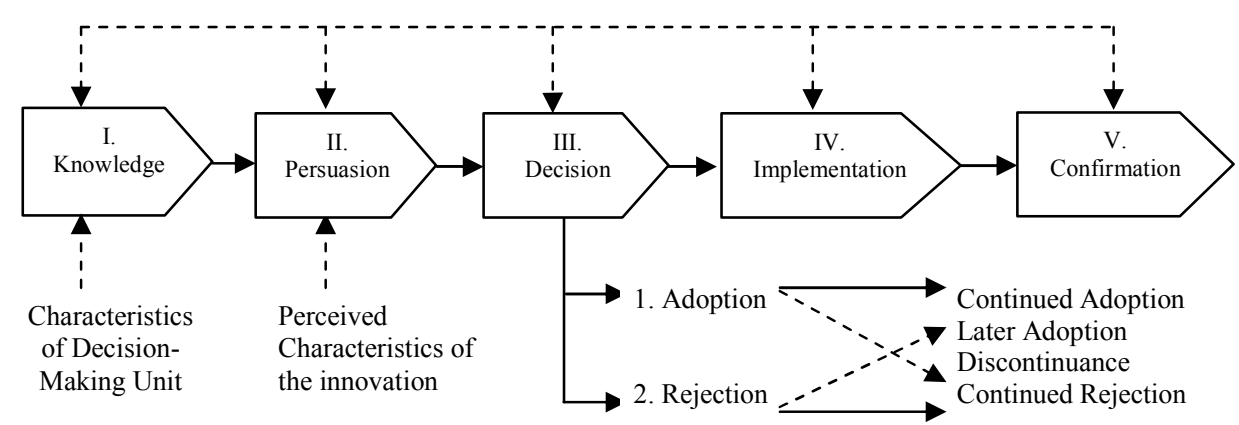

Figure 1. Diffusion of innovation (adopted from Rogers, 2003, pp:170)

The Theory of Reasoned Action (TRA) was formulated by Fishbein and Ajzen in 1975 (see Fig.2). TRA is one of the most fundamental and influential theories of human behavior and has been used to predict a wide range of behaviors. TRA is a tool used to gain deeper insight into how attitudes and beliefs are correlated with individual intentions to perform; that intention is determined by two factors: attitude towards behavior and subjective norm.

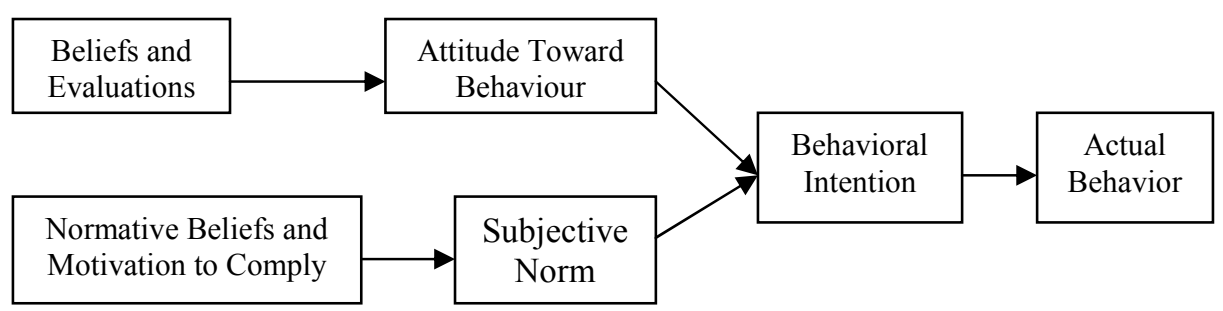

Figure 2. Theory of reasoned action (Fishbein and Ajzen, 1975) 
The Theory of Planned Behavior (TPB) proposed by Ajzen (1991) is a widely accepted theoretical referent for understanding individual acceptance of information system products. Ajzen (1991) extended TRA by adding the construct of perceived behavioral control (see Fig.3). In this theory, the intention to perform is determined by three factors: attitude toward behavior, subjective norm and perceived behavioral control. Perceived behavioral control refers to people's perceptions of their ability to perform a given behavior.

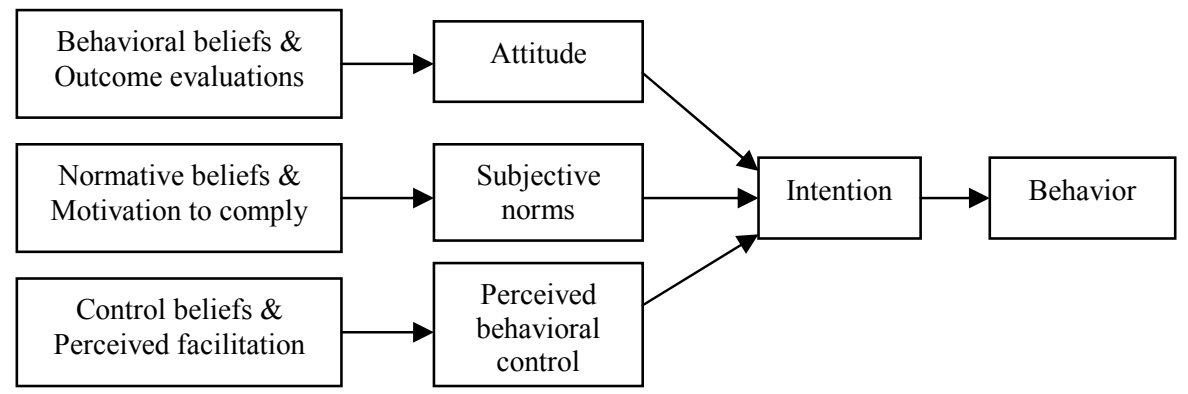

Figure 3. Theory of planned behavior (Ajzen, 1991)

The Technology Acceptance Model (TAM) was in essence adopted from Fishbein and Ajzen's TRA by Davis (1989) in order to explain the potential user's behavioral intention to make use of a technological innovation (see Fig.4). The purpose of this model is to predict the acceptability of a tool and to identify the modifications which must be brought to the system in order to make it acceptable to users. TAM is used to understand how people come to try new technologies. TAM has been widely applied to a diverse set of technologies and users. This model suggests that the acceptability of an information system is determined by two main factors: perceived usefulness and perceived ease of use. In other words, this model proposes that perceived ease of use and perceived usefulness are predictors as to the acceptance of information technology. Perceived usefulness is defined as being the degree to which a person believes that the use of a system will improve his or her performance. Perceived ease of use refers to the degree to which a person believes that using a given application is free of effort. In this model, perceived usefulness was found to be the most important factor that determined intention. 


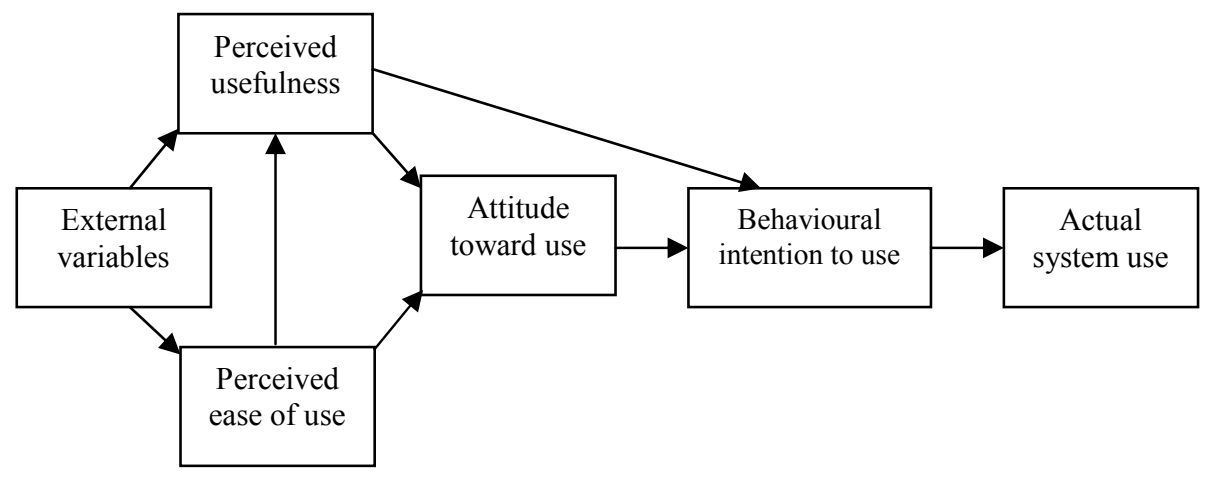

Figure 4. Technology Acceptance Model (Davis et al., 1989)

In the Technology Acceptance Model 2 (TAM 2), Venkatesh and Davis (2000) extended TAM by including additional key determinants of perceived usefulness and usage intention constructs. They aimed to determine the antecedents of external factors that affect perceived usefulness. These external factors are divided into two groups as social influence processes (subjective norm, voluntariness and imagination) and cognitive instrumental processes (job relevance, output quality, result demonstrability and perceived ease of use) (see Fig.5). Both voluntariness (mandatory usage) and experience (during early stages) have links between subjective norm and behavioral intention. This is indicated in the significant moderating effect in TAM 2 model (Venkatesh and Davis 2000).

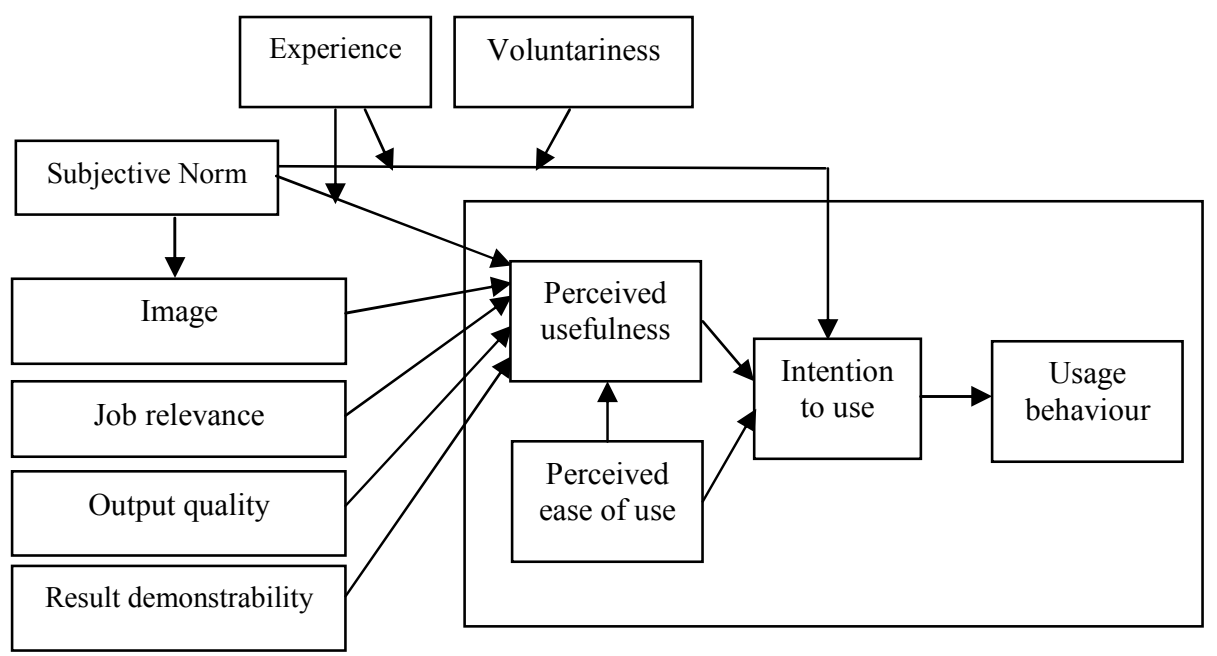

Figure 5. Technology Acceptance Model 2 (Venkatesh and Davis, 2000) 
The Unified Theory of Acceptance and Use of Technology (UTAUT) was created by Venkatesh, Morris, Davis and Davis (2003) (see Fig.6). They reviewed a large number of theories along with models and selected the appropriate structures from these theories and models. In their study the researchers reviewed user acceptance literature and discussed eight prominent models, compared these models and their extensions, formulated a unified model that integrated elements across the eight models, and empirically validated the unified model. The purpose of this unified model is to identify the behavioral intention placing factors such as gender, age, experience and voluntariness of use among variables such as performance expectancy, effort expectancy, social influence, and facilitating conditions which are believed to influence user acceptance and usage (Venkatesh et al., 2003). The research based on this model has shown that the previous models were able to explain $40 \%$ of users' acceptance of the technology, whereas UTAUT explains approximately $70 \%$ of users' acceptance of the technology.

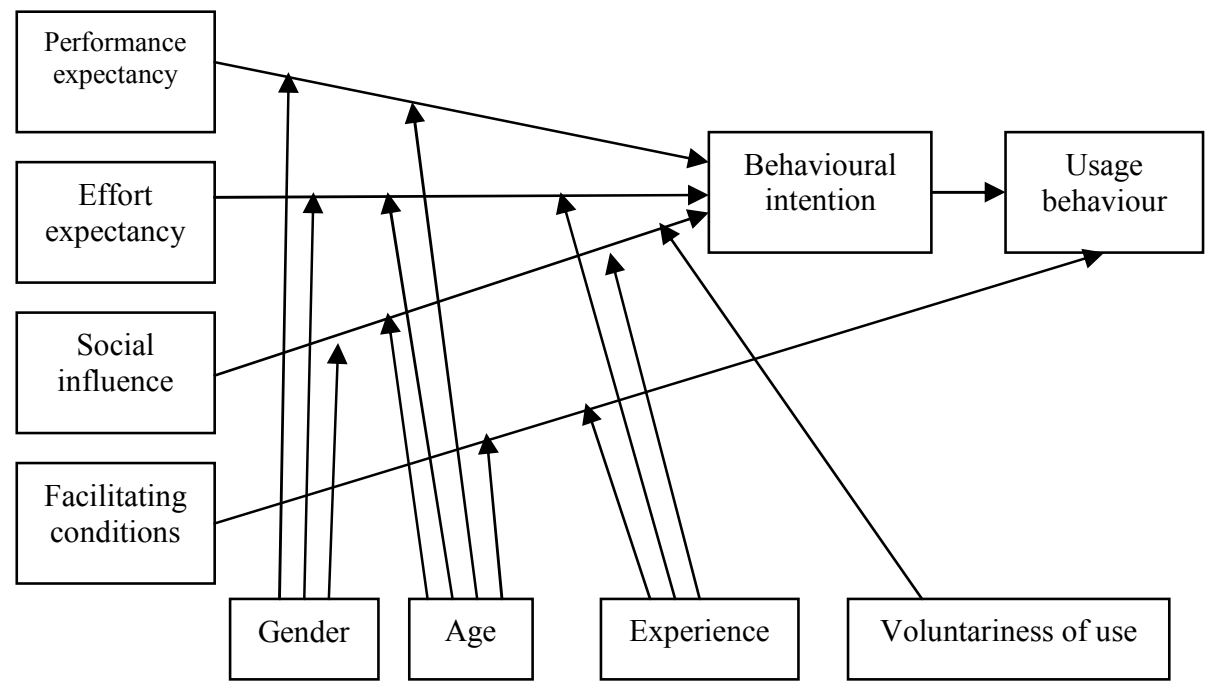

Figure 6. Unified theory of acceptance and use of technology (Venkatesh et al., 2003)

The main purpose of these models and theories is to explain the acceptance and adoption of innovations. Additionally, it is essential to develop a theoretical understanding of how and why technology is introduced, diffused and accepted. For this reason, many models and theories have been developed with regard to the diffusion, adoption and acceptance 
of innovation. Some of these are based on socio-physiological contexts and focus on the adoption of innovation. Conversely, others have focused on features of innovation. Since their various inceptions, they have been tested with various applications in numerous studies and have become the most widely applied models of user acceptance, usage, intention and diffusion of innovations.

There is also a quantity of previous TAM meta-analysis studies in the literature. King and He (2006) reviewed eighty-eight empirical published TAM-related studies that provided sufficient data to be deemed credible. Their study showed TAM to be a powerful and robust and widely used predictive model. TAM is also shown to be a 'complete mediating' model in that the effect of ease of use on behavioral intention is seen primarily through usefulness. Their study confirmed the value of using students as surrogates for professionals in some TAM studies. They also revealed the power of meta-analysis as a rigorous alternative to qualitative and narrative literature review methods.

In another meta-analysis, Ma and Liu (2004) conducted a study based on twenty-six selected empirical studies in order to synthesize the empirical evidence and avoided the use of correlation matrices. They examined the zero-order correlations between three key constructs: Ease of Use, Usefulness and Technology Acceptance. They indicated that the sampled studies employed similar instruments in terms of Ease of Use and Usefulness. They discovered that both the correlation between usefulness and acceptance and that between usefulness and ease of use are strong. However, they found that the relationship between ease of use and acceptance is comparatively weak and that its significance does not pass the fail-safe test.

Additionally, Legris, Ingham and Collerette (2003) reviewed twentytwo empirical TAM articles published from 1980 to early 2001 to investigate the structural relationships among the key TAM constructs. The result of their study was the underlining of three limitations to TAM research to date: the involvement of students, the type of applications and self-reported use. They revealed that although TAM is useful, it has to be integrated into a broader model which would include variables related to both human and social change processes, and to the adoption of the innovation model.

In another meta-analysis study, Schepers and Wetzels (2007) found a total of fifty-one useable articles, containing a total of sixty-three studies; of these, seven were either unpublished dissertations or conference proceedings. They examined the convergence or divergence of the published research results by conducting a quantitative meta-analysis of previous research on the TAM in an attempt to make well-grounded statements on the 
role of subjective norm. Results indicated a significant influence of the subjective norm on perceived usefulness and behavioral intention to use.

Finally, Turner et al. (2010) followed a formal systematic literature review based on a search of six digital libraries for their study. Their search identified seventy-nine relevant empirical studies in seventy-three articles. Their study examined the evidence that the TAM predicts actual usage using both subjective and objective measures of actual usage. They found that relatively few papers considered objective measures of actual usage. The results showed that behavioral intention to use is likely to be correlated with actual usage. However, the TAM variables which are perceived ease of use and perceived usefulness are less likely to be correlated with actual usage.

It is obvious that each of these meta-analysis research focuses on a different variable. Due to this reason, current study will be expected to provide a qualitative insight and contribute with a different perspective other than sample and effect size as in the above-given meta-analyses.

\section{METHOD}

In this study fifty related articles from different journals and conference proceedings were retrieved to review the research in detail with regard to the use of TAM between the years 1999-2010. These related articles were analyzed by using content analysis through an inductive approach. Thus, this study should be treated as a qualitative content analysis rather than being a meta-analysis paper, since meta-analysis studies requires much more than a literature review. For a meta-analysis study, a systematic literature review should be conducted and statistical analysis for investigated variables should be put forward. Hence, "A meta-analysis combines the results of several studies that address a set of related research hypotheses. In its simplest form, this is normally by identification of a common measure of effect size, of which a weighted average might be the output of a meta-analysis (Glass, 1976). Moreover, although there are numerous studies based on TAM2 and UTAUT (they can be thought of as "based on TAM"), this research only focused on the studies that are based on TAM. Hence, the current study can said to be a sub group of similar studies which aims to add value compared to doing a general review of TAM research.

\section{Scope of the Study}

The articles which had based their theoretical framework on TAM were the scope of this study. For this reason, fifty papers, which were published in thirty-two journals and nine conferences between 1999 and 2010, were reviewed in this study. These papers were mainly taken from journals such as; Computers \& Education, International Journal of Information Management, Journal of Computer Information Systems, Cyberpsychology 
\& Behavior, Decision Support Systems, Educational Computing Research and Behaviour \& Information Technology. All of these journals were accessed using the Elsevier-ScienceDirect, Springer, TÜBİTAK EKUAL, Taylor \& Francis, EBSCO Host and Blackwell databases. The search was performed on the well-known databases offered by the University Library and limited with the keywords as "Technology Acceptance Model (TAM)". From the search results, the first 50 articles and proceedings between the specified years were selected.

\section{Content Analysis}

According to Yıldırım and Şimşek (2008), the main objective in content analysis is to arrive at concepts and relations that will explain the collected data. The data summarized and interpreted in a descriptive analysis is processed to a deeper level in content analysis. Concepts and themes that are not realized by a descriptive approach are discovered as a result of content analysis. In this context, content analysis attempts to define the data. The main process in content analysis is to bring together the similar data within a framework of certain concepts and categories (themes) and interpret these by arranging them in a way that readers can understand. In addition, an inductive approach aims to reveal the underlying concepts of data and the relationships between these concepts by way of coding (Strauss and Corbin, 1990; Miles and Huberman, 1994).

Content analysis was used in four stages of the processing of the qualitative research data obtained from documents: (1) data coding, (2) finding themes, (3) the organization of themes and codes (4) identification and interpretation of findings (Yıldırım and Şimşek, 2006).

These articles were listed according to their citation: author name, publication date, article name, published journal or conference. Then, the selected articles were investigated and tabulated according to certain criteria, such as:

- Used variables

- Working areas

- Measurement items

- Results (based on the effectiveness of the selected variables)

Following this, all variables used in the articles were listed by utilizing the created table lists. At first step, the variables were listed for their effectiveness, meaningfulness and frequencies were observed. Then the variables that were close to each other were grouped under common themes. Grouped variables frequencies were observed again and variables ordered by their effectiveness. The grouped variables were listed according to their usage scores. Then, the first five most effective found and widely used 
variables were determined from the research papers. The same process was used for the least effective found and least used variables. In this way, the top five most effective found / used variables and the bottom five were determined.

The grouped variables were listed according to the dimensions of course/content, software and tools, learner/instructor and organizational issues. At the same time the study fields of the articles were listed. These study areas were grouped under the topics of education, business and others. In this context, coding was carried out according to previously identified concepts (scanning and selection criteria) and in this context themes were obtained. Then the data were organized, grouped according to themes and presented by making numerical in appropriate cases. Finally, the obtained findings were interpreted.

\section{FINDINGS}

Based on the content analysis of the papers, variables were grouped under main themes. After specification of these main headings, the variables were categorized and coded according to their research results and ordered by their level of effectiveness. The results of this analysis can be seen in Table 1.

Table 1. Effectiveness results of grouped variables in reviewed articles

\begin{tabular}{llcc}
\hline Variables & \multicolumn{3}{c}{ Number of articles } \\
& $\begin{array}{c}\text { Variables that } \\
\text { are found to be } \\
\text { the most } \\
\text { "effective" }\end{array}$ & $\begin{array}{c}\text { Variables } \\
\text { that are } \\
\text { found to be } \\
\text { "meaningful" }\end{array}$ & $\begin{array}{c}\text { Variables } \\
\text { that are } \\
\text { found to be } \\
\text { "ineffective" }\end{array}$ \\
\hline 1. Perceived Usefulness & 17 & 30 & 1 \\
2. Perceived Ease of Use & 11 & 28 & 3 \\
3. Intention & 2 & 37 & 0 \\
4. Examination of system and & 8 & 21 & 2 \\
5. $\quad$ Teols & 4 & 19 & 2 \\
6. Attitude & 2 & 18 & 0 \\
7. Subjective Norm & 5 & 7 & 0 \\
8. Usage of system and tools & 1 & 14 & 6 \\
9. Demographic characteristic & 3 & 9 & 1 \\
10. Perceived Enjoyment & 2 & 9 & 0 \\
11. Satisfaction & 0 & 10 & 0 \\
12. Organizational effects & 2 & 6 & 0 \\
13. Anxiety & 1 & 1 & 0 \\
\hline
\end{tabular}


According to Table 1, it can be concluded that the variable "Perceived Usefulness" is found to be the most effective one in seventeen research studies, this variables effect is found to be significant in thirty research studies, and only in one study it is determined to be found ineffective. Bearing this in mind, for this study the variable that is determined to be mostly used and found effective in research articles is "Perceived Usefulness". Based on a similar analysis, the top five variables are seen to be;

(1) Perceived Usefulness,

(2) Perceived Ease of Use,

(3) Intention,

(4) Investigation of System and Tools, and

(5) Technological Competency.

Similarly, when Table 1 is examined, it is obvious that the variable "Anxiety" is found to be most effective in only one research study and this variables effect was found as significant in only one study. With this in mind, the "Anxiety" is determined to be the least used and found ineffective variable for this study. The ordering of the five least used variables is;

(1) Anxiety,

(2) Organizational Effects,

(3) Satisfaction,

(4) Perceived Enjoyment, and

(5) Demographic Characteristics

Since the two variables, "Internal Locus of Control (self-control)" and "English Literacy", have been used only in one study and could not be integrated into the existing themes, they have not considered for this study.

The variables were categorized according to their inter-relatedness and considered under general themes. Based on this categorization, the four themes that emerged were; "course/content", "software and tools", "learner/instructor" and "organizational issues". During the categorization process the variable "satisfaction" was considered for three themes, namely, "course/content", "software and tools" and "learner/instructor". Both of the variables "usage of system and tools" and "investigation of system and tools" were considered under the theme "software and tools". The variables "technological competency", "demographic characteristic", "anxiety", "perceived enjoyment", "attitude", "intention", "perceived ease of use", "perceived usefulness" and "subjective norm" were considered under the theme "learner/instructor". The variable "organizational effects", which is categorized as "organizational support", "administration support" and "organizational culture", was considered under the theme "organizational issues" (see Table 2). 
Table 2. The variables and themes

\begin{tabular}{|c|c|c|c|}
\hline $\begin{array}{l}\text { Course/ } \\
\text { Content }\end{array}$ & $\begin{array}{l}\text { Software and } \\
\text { Tools }\end{array}$ & $\begin{array}{l}\text { Learner/ } \\
\text { Instructor }\end{array}$ & Organizational Issues \\
\hline \multirow[t]{10}{*}{ Satisfaction } & $\begin{array}{l}\text { Usage of system } \\
\text { and tools }\end{array}$ & $\begin{array}{l}\text { Technological } \\
\text { competency }\end{array}$ & Organizational Support \\
\hline & $\begin{array}{l}\text { Investigation of } \\
\text { system and tools }\end{array}$ & $\begin{array}{l}\text { Demographic } \\
\text { characteristics }\end{array}$ & Administration Support \\
\hline & Satisfaction & Anxiety & Organizational Culture \\
\hline & & Perceived enjoyment & \\
\hline & & Satisfaction & \\
\hline & & Attitude & \\
\hline & & Intention & \\
\hline & & Perceived ease of use & \\
\hline & & Perceived usefulness & \\
\hline & & Subjective norm & \\
\hline
\end{tabular}

On the other hand, the papers analyzed were mainly realized in order to address three working areas. The papers were mostly in the field of "education", preceded by the field of "business". Since there were few articles addressing matters other than education and business, they were kept within a separate "other" category. The specific topics taken into consideration for each working area is summarized in Table 3.

Table 3. Working areas

\begin{tabular}{|c|c|c|}
\hline Education & Business & Others \\
\hline $\begin{array}{l}\text { - Online learning platform / Online } \\
\text { learning community } \\
\text { - Online shopping environment } \\
\text { - Internet } \\
\text { - Computer Technology / Personal } \\
\text { Computer Technology use / Computer } \\
\text { Technologies / Usage of Computers / } \\
\text { Teachers Attitudes to Computers / Pre- } \\
\text { service Teachers at a Teacher Training } \\
\text { Institute } \\
\text { - Web } 2.0 \text { / Social Web / Social Networks } \\
\text { - Online education (E-learning) } \\
\text { - Information Systems } \\
\text { - Virtual Worlds/ Virtual Communities } \\
\text { - Learning-Object } \\
\text { - E-learning / Internet-based e-learning } \\
\text { tools } \\
\text { - Mobile wireless technology } \\
\text { - Tablet PCs } \\
\text { - Interactive whiteboard } \\
\text { - Decision support systems } \\
\text { - Outcomes assessment instrument } \\
\text { - WebCT }\end{array}$ & $\begin{array}{l}\text { - E-commerce technology } \\
\text { - Knowledge Management } \\
\text { System } \\
\text { - Enterprise resource Planning/ } \\
\text { (ERP system) } \\
\text { - Videoconferencing Systems } \\
\text { - Electronic banking technology } \\
\text { Online banking } \\
\text { - Telecommuting } \\
\text { - Internet Marketing } \\
\text { - Internet-based service/ Internet } \\
\text { consumer } \\
\text { - Corporate technology } \\
\text { acceptance }\end{array}$ & $\begin{array}{l}\text { - The usage of } \\
\text { SkypeOut } \\
\text { - Digital library } \\
\text { system }\end{array}$ \\
\hline
\end{tabular}




\section{DISCUSSION AND CONCLUSION}

This study was limited to the articles and proceedings which were published between 1999-2010 and keywords as "Technology Acceptance Model (TAM)". The publications were reached from well-known databases like Elsevier-ScienceDirect, Springer, TÜBİTAK EKUAL, Taylor \& Francis, EBSCO Host and Blackwell where the first 50 results were selected for the analysis. Hence, this study is limited with the number of publications, publication dates and databases offered by the University. The number of publications analyzed, changes in publication dates and selected search keywords might lead to different results. Consequently, these aspects should be regarded as the limitations for this study.

Although, the findings of this study are limited with only 50 articles and cannot be generalized, it is expected that the current study contributes to the existing literature from a different point of view. It is obvious that TAM attempts to explain and predict why users sometimes accept and sometimes reject information systems (IS). According to Legris, Ingham and Collerette (2003) "TAM has proven to be a useful theoretical model in helping to understand and explain usage behavior in technology acceptance (p. 202). It has been tested in much empirical research and the tools used with this model have proven to be of high quality and to yield statistically reliable results." Similarly, "TAM conceptualized usefulness and ease of use as important perceptions leading to intentions to adopt new systems" (Lee, Kozar and Larsen, 2003, p. 765).

The process of individual users' acceptance or rejection of technology is a complex process which cannot be explained by only one variable. There are many variables which contribute to the explanation of user acceptance of technology. For this reason, the full range of details should be investigated from a broad perspective, from the properties of any technology to the properties of any user (Dillon 2001). It is obvious that the models that attempt to reveal the technology acceptance are shaped through all of these variables. According to Lee, Kozar and Larsen, (2003), "TAM has been applied to different technologies (e.g. word processors, e-mail, WWW, GSS, Hospital Information Systems) under different situations (e.g., time and culture) with different control factors (e.g., gender, organizational type and size) and different subjects (e.g. undergraduate students, MBAs, and knowledge workers)" (p. 753). The variables that have arisen in many studies have made it easier to understand both the users and the acceptance processes. For these reasons identifying the variables have been previously used in TAM studies is very important. 
In this study, the variable "Perceived Usefulness" was found to be the leading variable in most of the articles in terms of effectiveness. Similarly, the variables "Perceived Ease of Use" and "Intention" were also mostly used and found effective in research articles. These three variables are the ones that were preferred mostly in the "Technology Acceptance Models" developed by the researchers. Again, content analysis revealed that the two variables which predict "Intention" were found to be "Perceived Usefulness" and "Perceived Ease of Use".

Furthermore, two other variables, "Examination of System and Tools" and "Technological Competency" were also among those that were both mostly used and found effective in research articles. The variable "Examination of System and Tools" consists of different components such as quality, adoptability, accessibility and visuality of the tool or the system. The variable "Technological Competency" covers the issues of self-efficacy, experience, ability, effectiveness and active usage for both learners and trainers. These kinds of individual differences play an important role in the acceptance process of technology by users, and have thus been considered in many studies by different researchers. The variable "Anxiety" was to be found least effective variable in related articles. "Anxiety" refers to the worry and perceived risk towards computers.

Although numerous attempts have been made to add other variables to existing ones, the main variables that the "Technology Acceptance Model" was based on remain the most effective found. This is an interesting finding given that over the last 20 years many issues relating to technology, including the technology itself, have shown remarkable changes. This finding brings us to the understanding that whatever the shape, color, size and property of the technology, acceptance of that technology can ultimately be determined by using the same variables.

Literature review of the current research revealed that the research on TAM is mainly converged on the education and business environments. This finding can be interpreted as the information flow is important for these areas. Since the information uses Internet to quickly flow, diffusion of technology is inevitable for these two fields. Main concepts coming forth in this picture for today are information, technology, education and business, which can be thought in a cycle by affecting each other in a two directional way. For this reason, diffusion of any innovation from these fields which has inter-relationships cannot be avoided.

By chance, most of the papers reviewed for current research were about educational environments. The field of education is an important field which may be enhanced by the use of appropriate technologies. Hence, the most important components of this process, namely teachers and students, should 
follow contemporary literature for innovative approaches and try to integrate these into their curriculum in an effective and efficient manner. The acceptance of technology gains importance at this stage and thus, in the field of education, not only the effective usage and integration of technology, but also the sustainability of used technologies is very much required. This raises the question of whether other disciplines, such as business, have to be more accepting - without questioning - of technology in order to succeed, or is the education world more resistant to the use technology within educational settings?

Another point that may be of importance is the categorization of the variables. Placing particular emphasis on education as a field of study runs parallel to the matching dimension within the grouped variables. Although researchers categorized all of the variables into four main headings, the variables that are considered most important are those related with the human components, i.e. the learner and instructor. Since the model is trying to explain acceptance of technology by its user, it is normal to consider user properties and find them as being the most effective ones.

To summarize this study, it may be pertinent for further research to consider the top five variables, namely "Perceived Usefulness", "Perceived Ease of Use", "Intention", "Investigation of System and Tools", and "Technological Competency".

\section{Implications for Future Research}

This research has revealed that, for an easier acceptance process, technology should not only be useful but should also be easy to use. However, the question of 'what makes technology useful and easy to use' is another concern, which has to be answered. Thus, in future research studies factors contributing to usefulness and ease of use may be investigated. Another research may focus on investigating the other areas where the technology acceptance is important and can be researched.

Nowadays, there are various technologies which can be used by any individual without having any technology competence. Although these devices minimize technology competencies, the variables predicting acceptance of people for using these devices may also show variety. Hence, in the future studies possible changes of predictor variables for new emerging technologies should be explored.

In the future, technology will continue to change and as users we will also continue to adapt ourselves and learn how to cope with the new features of upcoming technologies. During this process, investigating personal variables that affect this adaptation process will be still important. On the other hand, it is also important to examine the role and effect of technology 
in terms of change and transformation processes in detail. The use and diffusion of technology in education and other areas, might gain much from the results of such research studies. At least for now, we are able to identify the variables which directly influence this process. Furthermore, our search to reveal more will continue evermore.

\section{REFERENCES}

Ajzen, I. (1991). The theory of planned behavior. Organizational Behavior and Human Decision Processes, 50(2), 179-211.

Chuttur, M.Y. (2009). Overview of the technology acceptance model: Origins, developments and future directions. Indiana University, USA. Sprouts: Working Papers on Information Systems, 9(37).

Davis, F. D. (1989). Perceived usefulness, perceived ease of use and user acceptance of information technology. MIS Quarterly, 13(3), 318-340.

Dillon, A. (2001). User acceptance of information technology. In W. Karwowski (Eds.), Encyclopedia of Human Factors and Ergonomics. London: Taylor and Francis.

Dillon, A. \& Morris, M. (1996). User acceptance of new information technology: Theories and models. In M. Williams (Eds.), Annual Review of Information Science and Technology, Medford NJ: Information Today, 31, 3-32.

Fishbein, M., \& Ajzen, I. (1975). Belief, attitude, intention and behavior: An introduction to theory and research. Addison-Wesley, Reading, MA.

Fusilier, M., Durlabhji, S. \& Cucchi, A. (2008). An investigation of the integrated model of user technology acceptance: Internet user samples in four countries. Journal of Educational Computing Research, 38(2), 155-182.

Glass, G. V. (1976). Primary, secondary, and meta-analysis of research. Educational Researcher, 5, 3-8.

King, W. R. \& He, J. (2006). A meta-analysis of the technology acceptance model. Information \& Management, 43, 740-755.

Lee, Y., Kozar, K.A. \& Larsen, K.R.T. (2003). The technology acceptance model: Past, present, and future. Communications of the Association for Information Systems, 12(50), 752-780.

Legris, P., Ingham, J. \& Collerette, P. (2003). Why do people use information technology? A critical review of the technology acceptance model. Information \& Management, 40(3), 191-204.

Ma, Q. \& Liu, L. (2004). The technology acceptance model: A meta-analysis of empirical findings. Journal of Organizational and End User Computing, 16(1), 59-72.

Miles, M. \& Huberman, A.M. (1994). Qualitative Data Analysis. Thousand Oaks, CA: Sage Publications.

Rogers, E.M. (2003). Diffusion of innovations (5th edition). The Free Press. New York. 
Schepers, J. \& Wetzels, M. (2007). A meta-analysis of the technology acceptance model: Investigating subjective norm and moderation effects. Information \& Management, 44, 90-103.

Strauss, A. and Corbin, J. (1990). Basics of qualitative research: Grounded theory procedures and techniques. Sage Publications.

Turner, M., Kitchenham, B., Brereton, P., Charters, S. \& Budgen, D. (2010). Does the technology acceptance model predict actual use? A systematic literature review. Information and Software Technology, 52, 463-479.

Venkatesh, V. \& Davis, F.D. (2000). A theoretical extension of the technology acceptance model: four longitudinal field studies. Management Science, 46(2), 186-204.

Venkatesh, V., Morris, M., Davis, G. \& Davis, F. (2003). User acceptance of information technology: Toward a unified view. MIS Qarterly, 27(3), 425-478.

Yıldırım, A. \& Şimşek, H. (2006). Sosyal Bilimlerde Nitel Araștırma Yöntemleri [Qualitative Research Methods in Social Sciences]. (5th Edition). Ankara: Seçkin Yayıncılık.

Yıldırım, A. \& Şimşek, H. (2008). Sosyal Bilimlerde Nitel Araştırma Yöntemleri [Qualitative Research Methods in Social Sciences]. (6th Edition). Ankara: Seçkin Yayıncılık.

Yuena, A. H.K. \& Ma, W. W.K. (2008). Exploring teacher acceptance of e-learning technology. Asia-Pacific Journal of Teacher Education, 36(3), 229-243. 